\title{
Next-Generation Biomaterials for Bone-Tissue Regeneration: Mg-Alloys on the Move
}

\author{
RIDA Batool Naqvi ${ }^{a}$, YASIR Faheem Joya ${ }^{b}$ \\ and MUHAMMAD Ramzan Abdul Karim ${ }^{\mathrm{C}^{*}}$
}

\author{
Faculty of Materials and Chemical Engineering, Ghulam Ishaq Khan Institute of Engineering \\ Sciences and Technology, Topi-23640, Pakistan \\ arida_gemini14@yahoo.com, byasir.joya@giki.edu.pk, *cramzan.karim@giki.edu.pk
}

\begin{abstract}
Keywords: Mg-alloys, Metal-matrix composites, Bone implants, Bio-mechanical properties, Corrosion rate, Biodegradation
\end{abstract}

\begin{abstract}
Disorders related to the bone health are becoming a significant concern due to subsequent rise in ageing human population. It is estimated that more than two million bone-surgeries are performed worldwide with an annual cost of $\$ 2.5$ billion. In order to replace damaged bone-tissues and restore their function, biomaterials consisting of stainless steels, cobalt-chromium and titanium alloys are implanted. However, these permanent (non-biodegradable) implants often lead to stressshielding effects and ions release as they interact with the cells and fluids in the body. It is required to overcome these issues by improving the quality of implant materials and increasing their service life. Recently, research in biodegradable materials, consisting of magnesium alloys in particular, has received global attention owning to their biocompatibility and closer mechanical properties to the natural bone. However, due to their rapid corrosion rate in the body fluids, clinical applications of mg-alloys as viable bone-implants have been restricted. A number of mg-alloys have been tested since (both in-vivo and in-vitro) to optimize their biodegradation rare and corrosion properties. The present review summarizes the most recent developments in $\mathrm{Mg}$-alloys designed with biodegradation tailored to the bone-cells growth and highlights the most successful ways to optimize their surface properties for optimum cell/material interaction.
\end{abstract}

\section{Introduction}

Bone defects and associated health problems affect a significant number of human population throughout the world. It is estimated that 1.5 million people suffer from bone fracture every year [1]. Approximately one-third of these patients are hospitalized and subjected to surgeries for implant replacement incurring significant health care expenditure [2]. Due to their superior mechanical properties, metallic biomaterials have dominated the market associated with boneimplants because they provide sufficient load-bearing capacity to the implant. This is one of the reasons that first-generation biomedical implants made extensive use of stainless steels, cobaltchromium and titanium alloys [3-4] due to their high demand for load-bearing applications [5-6]. Key mechanical properties of some of these biomedical alloys are shown in Table 1 [7-12].

These biomaterials were developed from 1960 to 1970 with the goal to achieve a suitable combination of physical properties to replace the effected tissues with minimal toxicity. It was not until 1980 that problems with stainless steel and titanium-based implants were surfaced in the form of stress-shielding phenomenon [13-14] and release of ions through corrosion and wear process, which could cause infections and diseases [15-16]. These permanent implants were essentially designed to be inert i.e. not reactive to the physiological conditions of the human body. In addition to metallic materials, ceramic-based biomaterials such as alumina, zirconia and porous ceramics were also investigated in the $1^{\text {st }}$ generation biomaterials. However due to their brittleness and allergic effects, they found limited use [17]. Polymers such as polyurethane, acrylic resins, polypropylene were also investigated but they found limited applications as load-bearing implants. Amid of their wide scale applications, these biomaterials offered limited bioactivity which was strongly required for maximum tissue/cells interaction with the implant surface. 
Table 1. Mechanical properties of typical biomedical alloys [7-12]

\begin{tabular}{|c|c|c|c|c|c|}
\hline Material & $\begin{array}{l}\text { Elastic } \\
\text { Modulus } \\
\text { [GPa] }\end{array}$ & $\begin{array}{l}\text { Yield } \\
\text { Strength } \\
\text { [MPa] }\end{array}$ & $\begin{array}{l}\text { Ultimate } \\
\text { Strength } \\
\text { [MPa] }\end{array}$ & Merits & Demerits \\
\hline $\begin{array}{l}\text { Stainless steel } \\
\text { 316L }\end{array}$ & $196-210$ & $170-750$ & 465-950 & $\begin{array}{l}\text { High strength and } \\
\text { mechanical } \\
\text { properties }\end{array}$ & $\begin{array}{l}\text { Dissolves } \\
\text { rapidly and also } \\
\text { causes erosion } \\
\text { of adjacent } \\
\text { bones }\end{array}$ \\
\hline Co-Cr-Mo & $220-230$ & $275-1585$ & $600-1785$ & $\begin{array}{l}\text { Corrosion } \\
\text { resistance even in } \\
\text { chloride } \\
\text { environment. } \\
\text { Excellent fatigue } \\
\text { strength and wear } \\
\text { resistance }\end{array}$ & $\begin{array}{l}\text { Expensive. High } \\
\text { elastic modulus } \\
\text { (200-230 GPa } \\
\text { causing stress } \\
\text { yielding }\end{array}$ \\
\hline $\begin{array}{l}\text { Ti grade } 4 \\
\text { (ASTM F67) }\end{array}$ & $105-115$ & $692-795$ & $785-860$ & $\begin{array}{l}\text { Highest tensile } \\
\text { and yield } \\
\text { strengths, highly }\end{array}$ & Low shear \\
\hline Ti6Al4V & 110 & $850-900$ & $960-970$ & $\begin{array}{l}\text { integrated to the } \\
\text { bone. Moderate } \\
\text { elastic modulus }\end{array}$ & $\begin{array}{l}\text { resistance. } \\
\text { Expensive }\end{array}$ \\
\hline
\end{tabular}

The $2^{\text {nd }}$ generation biomaterials consisting of bioactive constituents were developed from 1980 to 2000 with the ability to interact with biological environment in order to increase the cell/material response and bonding with the tissues. Most of the research in this era was focused on surface modifications of $1^{\text {st }}$ generation biomaterials to increase bonding between the bone cells and the implant surface. Some of the new biomaterials in this class also had the ability to degrade while the new tissues regenerate such as calcium phosphate, bioactive glasses, glass ceramics and composites. However, the presence of silicon in bioactive glasses and glass ceramics led to weakening of bones causing osteogenesis [18].

The lower bioactivity of the metals was enhanced by depositing bioactive coatings of a ceramic or through chemical modification of the surface by reacting with calcium phosphate. Biodegradable and bioactive polymers such as polyglycolide (PGA), polylactide (PLA), poly( $\epsilon$-caprolactone) (PCL), polyhydroxybutyrate (PHB), polyorthoester, chitosan, poly(2-hydroxyethyl-methacrylate) (PHEMA) and other hydrogels were extensively studied [19] during this period. However, most of these biomaterials offered low mechanical strengths and high degradation rates and as such could not be applied successfully as load bearing implants.

The $3^{\text {rd }}$ generation biomaterials consisted of materials with a combined effect of biodegradability and bioactivity. It involved improved design of materials that were biodegradable, biocompatible with inherent ability to degrade into non-toxic constituents. Among various biomaterials from this class, $\mathrm{Mg}$ showed higher biocompatibility due to its mechanical properties [20] matching to the cortical bone as shown in Table 2. This helped to reduce the stress-shielding effects as observed by the $1^{\text {st }}$ and $2^{\text {nd }}$ generation biomaterials. Moreover, $\mathrm{Mg}$ is essential to human metabolism and is naturally found in bone tissues whereas the excess is harmlessly excreted by the body. It has been reported that $\mathrm{Mg}$-alloys produced no inflammatory reactions to the cells and tissues during and after its biodegradation [21].

Mg-alloys for Biomedical Implants. Unalloyed $\mathrm{Mg}$ in the as-cast condition has a very low strength, at just under $30 \mathrm{MPa}$, but a fast corrosion rate i.e. $2.89 \mathrm{~mm} /$ year in $0.9 \% \mathrm{NaCl}$ solution [26]. Therefore, alloying additions have been required to improve the mechanical properties by strengthening through solid-solution, precipitation or grain-refinement. However most of the alloying elements have limited solubility in $\mathrm{Mg}$ therefore limiting their use to modify the 
mechanical properties. Mostly investigated Mg-based alloys with biodegradability, such as $\mathrm{Mg}-\mathrm{Al}-$ based, $\mathrm{Mg}-\mathrm{Zn}$-based and most $\mathrm{Mg}$-rare earth (RE)-based alloys, have obvious precipitation hardening due to high solubility of the secondary element in $\mathrm{Mg}$. Alloy systems such as $\mathrm{Mg}-\mathrm{Ca}$ and $\mathrm{Mg}-\mathrm{Si}$ did not support strengthening through heat treatment.

Table 2. Properties of Mg and natural bone [22-25]

\begin{tabular}{lll}
\hline Properties & Natural Bone & Mg \\
\hline Density $\left[\mathrm{g} / \mathrm{cm}^{3}\right]$ & $1.8-2.1$ & $1.74-2$ \\
Elastic Modulus $[\mathrm{GPa}]$ & $3-20$ & $41-45$ \\
Yield Strength $[\mathrm{MPa}]$ & $130-180$ & $65-100$ \\
Fracture toughness $[\mathrm{MPa} \sqrt{\mathrm{m}}]$ & $3-6$ & $15-40$ \\
\hline
\end{tabular}

It has been observed that strengthening by grain refinement is much more effective in $\mathrm{Mg}$ alloys compared to others. Mg when alloyed with Zinc or Zirconium has been observed to reduce/refine the gran size thus leading to improve the yield strength as well as impart corrosion resistance. Zinc is a nontoxic element that is essential for immune system [27] and thus adds to the biocompatibility of $\mathrm{Mg}$. Similarly, calcium (Ca) is the most abundant mineral in the human body that is important for bone function. The solubility of $\mathrm{Ca}$ in $\mathrm{Mg}$ is about $1.34 \mathrm{wt} . \%$, and under the equilibrium conditions, $\mathrm{Ca}$ contributes to solid solution strengthening, grain boundary strengthening, precipitation and grain-refinement [28].

Due to their optimum biodegradation in-vivo, $\mathrm{Mg}$-Al-Zn based alloys have been among the most widely researched biomedical alloys for typical bone-implants (such as bone screws, plates) and other bone fixation implants [29]. Aluminum added to $\mathrm{Mg}$ could provide better corrosion resistance [30]. During the past decades, several new alloy systems such as Mg-Al-Ca [31], Mg-Re$\mathrm{Zn}-\mathrm{Zr}, \mathrm{Mg}-\mathrm{Sc}-\mathrm{Mn}$ and Mg-Y-Re-Zr [32] were developed for biomedical applications. In addition, binary $\mathrm{Mg}-\mathrm{Ag}$ alloys were also designed as implant materials to combine the favorable properties of $\mathrm{Mg}$ with the well-known antibacterial property of silver [32-33]. In spite of these alloys, the extensive applications of Mg-based implants have been limited by their high corrosion/degradation rates and consequent loss in mechanical integrity after implantation in the human body [20, 34-35]. It is therefore essential to improve the surface properties of potential Mg-alloys in order to realize their clinical application. Table 3 shows the mechanical and corrosion properties of a variety of $\mathrm{Mg}-$ alloys [36-38].

Table 3. Mechanical properties of Mg-alloys and their corrosion rates

\begin{tabular}{cccccccc}
\hline Alloy & Condition & $\begin{array}{c}\text { YS } \\
{[\mathbf{M P a}]}\end{array}$ & $\begin{array}{c}\text { UTS } \\
{[\mathbf{M P a}]}\end{array}$ & $\begin{array}{c}\text { Elong. } \\
{[\%]}\end{array}$ & $\begin{array}{c}\text { In-vitro } \\
\text { Corrosion Rate } \\
{[\mathbf{m m} / \mathbf{y e a r}]}\end{array}$ & $\begin{array}{c}\text { Corrosion } \\
\text { Medium }\end{array}$ & Ref. \\
\hline $\mathrm{Mg}-1 \mathrm{Ca}$ & As-cast & 40 & 71.38 & 1.87 & 12.56 & $\mathrm{SBF}$ & {$[36]$} \\
$\mathrm{Mg}-1 \mathrm{Sn}$ & As-cast & 79 & 194 & 20 & 2.54 & $\mathrm{SBF}$ & {$[37]$} \\
$\mathrm{Mg}-1 \mathrm{Ag}$ & As-cast & 23.5 & 116.2 & 13.2 & 8.12 & $\mathrm{SBF}$ & {$[37]$} \\
$\mathrm{Mg}-1 \mathrm{Mn}$ & As-cast & 28.5 & 86.3 & 7.5 & 2.46 & $\mathrm{SBF}$ & {$[37]$} \\
$\mathrm{Mg}-1 \mathrm{Zn}$ & As-cast & 25.5 & 134 & 18.2 & 1.52 & $\mathrm{SBF}$ & {$[37]$} \\
$\mathrm{Mg}-1 \mathrm{Zr}$ & As-cast & 67.5 & 172 & 27 & 2.20 & $\mathrm{SBF}$ & {$[37]$} \\
$\mathrm{Mg}-2 \mathrm{Sr}$ & As-rolled & 147.3 & 213.3 & 3.15 & 0.87 & Hanks & {$[38]$} \\
$\mathrm{Mg}-6 \mathrm{Zn}$ & As- & 169.5 & 279.5 & 18.8 & 0.16 & $\mathrm{SBF}$ & {$[37]$} \\
\hline
\end{tabular}

Improving Surface Properties of Mg-alloys. Irrespective of the advantages associated with $\mathrm{Mg}$ $\mathrm{Al}-\mathrm{Zn}, \mathrm{Mg}-\mathrm{Zn}-\mathrm{Zr}$ and $\mathrm{Mg}-\mathrm{Ca}$ based alloys, their degradation rates were still higher than required for orthopedic implants. In order to decrease the degradation/corrosion rate of Mg-alloys two strategies have been mostly investigated:

1. Altering the composition and microstructure, including the grain size and texture of the base material, not only through alloying but also through the development of optimized manufacturing methods and the availability of suitable raw materials. 
2. Carry out surface treatments or form coatings which produce protective ceramic, polymer or composite layers [39-45].

Both of these options have offered limited solutions as selecting the type and concentration of the alloying elements to achieve suitable mechanical properties with the optimised degradation profile has not been commercially successful. Clinicians stress the relevance of toxicity assessment that must be considered during material design. On the other hand, the surface treatments of Mgalloys have produced appreciable initial results [46]. Bioactive coatings consisting of hydroxyapatite (HA) and its derivatives have shown promising effect to reduce the degradation rate of $\mathrm{Mg}$ and improve the host response for bone tissue regeneration. However, in many cases satisfactory results were not achieved, typically due to crack formation or poorly controlled adjustment of the specific calcium phosphate phases.

Mg-alloys Composites. Following the discussion in earlier section, a third solution has been gradually setting its pace worldwide that is related to the development of Mg-alloy composites. In this context more research is required in designing and fabricating innovative $\mathrm{Mg}$-alloy composites with reinforcements, which are more biocompatible and corrosion resistant. Recently, Mg-based metal matrix composites (MMCs) with bioactive reinforcements, such as calcium phosphate (CaP), is an interesting development [47]. However, further investigation would be required to analyze the effect of $\mathrm{CaP}$ and $\mathrm{HA}$ derivatives on the degradation rates of $\mathrm{Mg}$-alloy and understanding their structure, property relationship to fabricate commercially viable bone-implants [48]. The reason to using $\mathrm{HA}$ as a reinforcement in Mg-alloys is related to its chemical resemblance to the mineral part of the natural bone.

Sun et al. [25] investigated the development of $\mathrm{HA} / \mathrm{Mg}-\mathrm{Zn}-\mathrm{Zr}$ nanocomposite structure to improve the properties of these particular Mg-alloys. A number of composite samples with varying HA concentrations were compared through immersion tests in the simulated body fluid (SBF) as shown in Table 4.

Table 4. Properties of Mg-Zn-Zr based nano-composites [25]

\begin{tabular}{lccccc}
\hline Composite & $\begin{array}{l}\mathbf{0 . 2 \%} \\
\text { Yield } \\
\text { Strength } \\
{[\mathbf{M P a}]}\end{array}$ & $\begin{array}{l}\text { Tensile } \\
\text { Strength } \\
{[\mathbf{M P a}]}\end{array}$ & $\begin{array}{l}\text { Elongation } \\
{[\%]}\end{array}$ & $\begin{array}{l}\text { Corrosion } \\
\text { Potential } \\
\mathbf{E}_{\mathbf{c o r r}}[\mathbf{V}]\end{array}$ & $\begin{array}{l}\text { Charge } \\
\text { transfer } \\
\text { resistance, Rt } \\
{\left[\mathbf{O h m}^{*} \mathbf{c m}^{2}\right]}\end{array}$ \\
\hline $\mathrm{Mg}-3 \mathrm{Zn}-0.5 \mathrm{Zr}(\mathrm{C0})$ & 238 & 275 & 14.3 & -1.88 & 2.22 \\
$\mathrm{Mg}-3 \mathrm{Zn}-0.5 \mathrm{Zr}-0.5 \mathrm{HA}$ & 255 & 281 & 15.4 & -1.68 & 4.2 \\
$(\mathrm{C} 1)$ & 256 & 285 & 18.6 & -1.62 & 8 \\
$\mathrm{Mg}-3 \mathrm{Zn}-0.5 \mathrm{Zr}-1 \mathrm{HA}(\mathrm{C} 2)$ & 275 & 302 & 20.9 & -1.65 & 5.36 \\
$\mathrm{Mg}-3 \mathrm{Zn}-0.5 \mathrm{Zr}-1.5 \mathrm{HA}$ & $275)$ & & & \\
$(\mathrm{C} 3)$ & & & &
\end{tabular}

It can be observed that composite $\mathrm{C} 2$ offered higher corrosion resistance while the composite $\mathrm{C} 3$ offered better tensile and yield strength. The mechanical properties of the composite with $1.5 \mathrm{wt} \%$ HA exhibited higher ultimate tensile strength, yield strength and elongation, which are significantly greater than those of monolithic $\mathrm{Mg}-3 \mathrm{Zn}-0.5 \mathrm{Zr}$ alloy by $9.8 \%, 15.5 \%$ and $46.2 \%$, respectively. A similar increase in the yield strength and tensile strength is also found in $\mathrm{C} 1$ and $\mathrm{C} 2$ composite samples.

Sunil et al. [49] investigated the fabrication of Mg-based MMCs for degradable implants with nano-HA powder. The purpose was to develop a lamellar structured Mg-composite prepared with 8, 10 and 15 wt.\% nanosize HA reinforcement that were fabricated by ball milling and spark plasma sintering. After milling the $\mathrm{Mg}$ particles plastically deformed into thin flakes covered with HA particles. Corrosion resistance was found to be higher for $\mathrm{Mg}-10 \mathrm{HA}$ composite compared to other samples. Fracture toughness was higher for pure $\mathrm{Mg}$ and $\mathrm{Mg}-8 \mathrm{HA}$ samples but decreased with further increase in HA. Therefore, $\mathrm{Mg}-8 \mathrm{wt} . \% \mathrm{HA}$ and $\mathrm{Mg}-10 \mathrm{wt} . \% \mathrm{HA}$ were found to be promising composites for implants as they exhibited optimum corrosion resistance and mechanical behavior. 
Fig. 1 presents the potentio-dynamic polarization curves of the samples that shows an increase in corrosion resistance as the HA content was increased up to $10 \%$. The corresponding electrochemical parameters are tabulated in Table 5 [49].

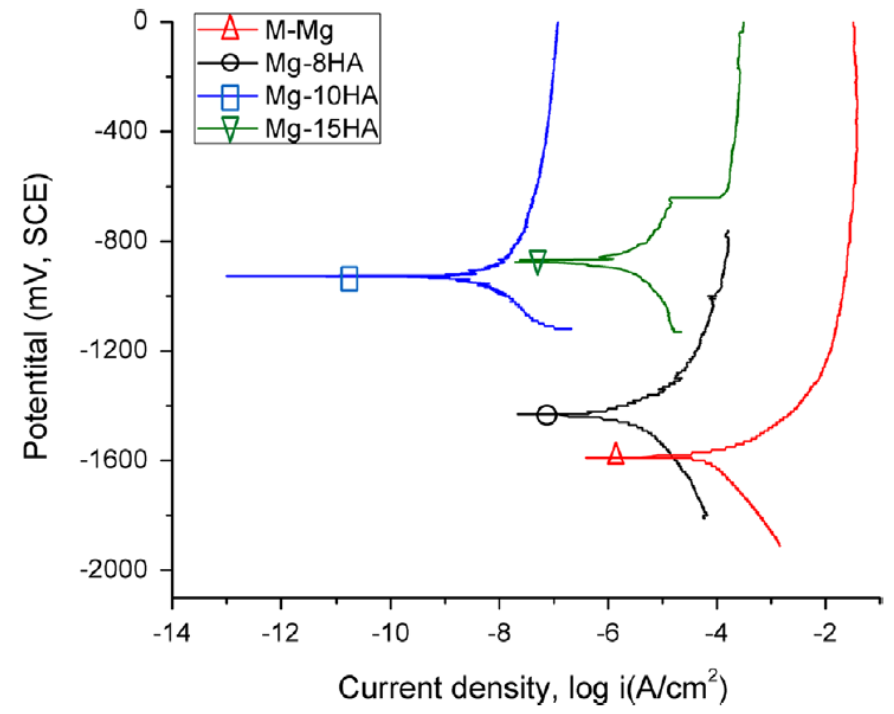

Fig. 1. Potentio-dynamic polarization curves [49] (with permission from Elsevier)

Table 5. Electrochemical parameters obtained from potentio-dynamic polarization plots [49]

\begin{tabular}{lcc}
\hline Sample & $\mathbf{E}_{\text {corr }}[\mathbf{V}]$ & $\mathbf{I}_{\text {corr }}\left[\mathbf{A} / \mathbf{c m}^{2}\right]$ \\
\hline $\mathrm{M}-\mathrm{Mg}$ & $-1.586 \pm 0.017$ & $20.987 \pm 0.45 \times 10^{-3}$ \\
$\mathrm{Mg}-8 \mathrm{HA}$ & $-1.434 \pm 0.051$ & $4.387 \pm 0.31 \times 10^{-3}$ \\
$\mathrm{Mg}-10 \mathrm{HA}$ & $-0.939 \pm 0.039$ & $2.67 \pm 0.27 \times 10^{-4}$ \\
Mg-15HA & $-0.872 \pm 0.042$ & $3.397 \pm 0.63 \times 10^{-3}$
\end{tabular}

The microstructural properties have a direct influence on the surface properties such as corrosion rate and host response to the bone cells. Fig. 2 shows the surface morphologies of the samples after electrochemical test observed using SEM. It is observed that each composite suffered from localized, inter-lamellar and pitting corrosion. Among all the samples, moderate inter-lamellar corrosion and lower pitting was observed for $\mathrm{Mg}-10 \mathrm{HA}$ composite.
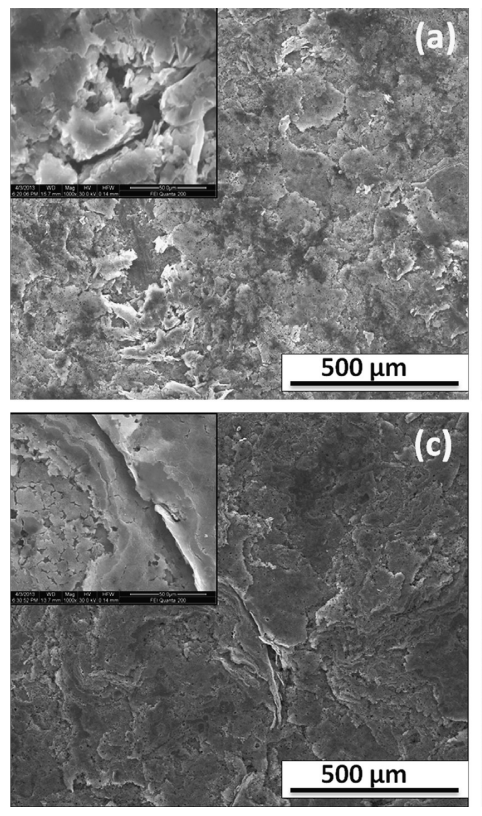
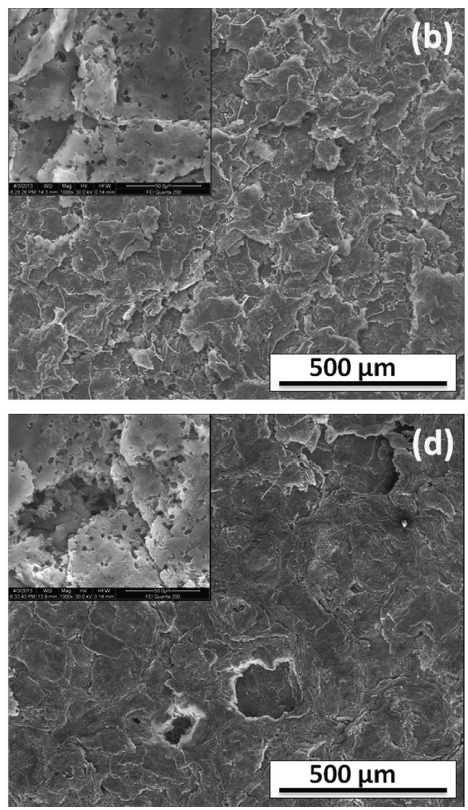

Fig. 2. Surface morphologies of the samples after electrochemical test observed using SEM at 50x magnification: (a) M-Mg, (b) $\mathrm{Mg}-8 \mathrm{HA},(\mathrm{c}) \mathrm{Mg}-10 \mathrm{HA}$ and (d) $\mathrm{Mg}-15 \mathrm{HA}$ (insets at 1000x) [49] (with permission from Elsevier) 

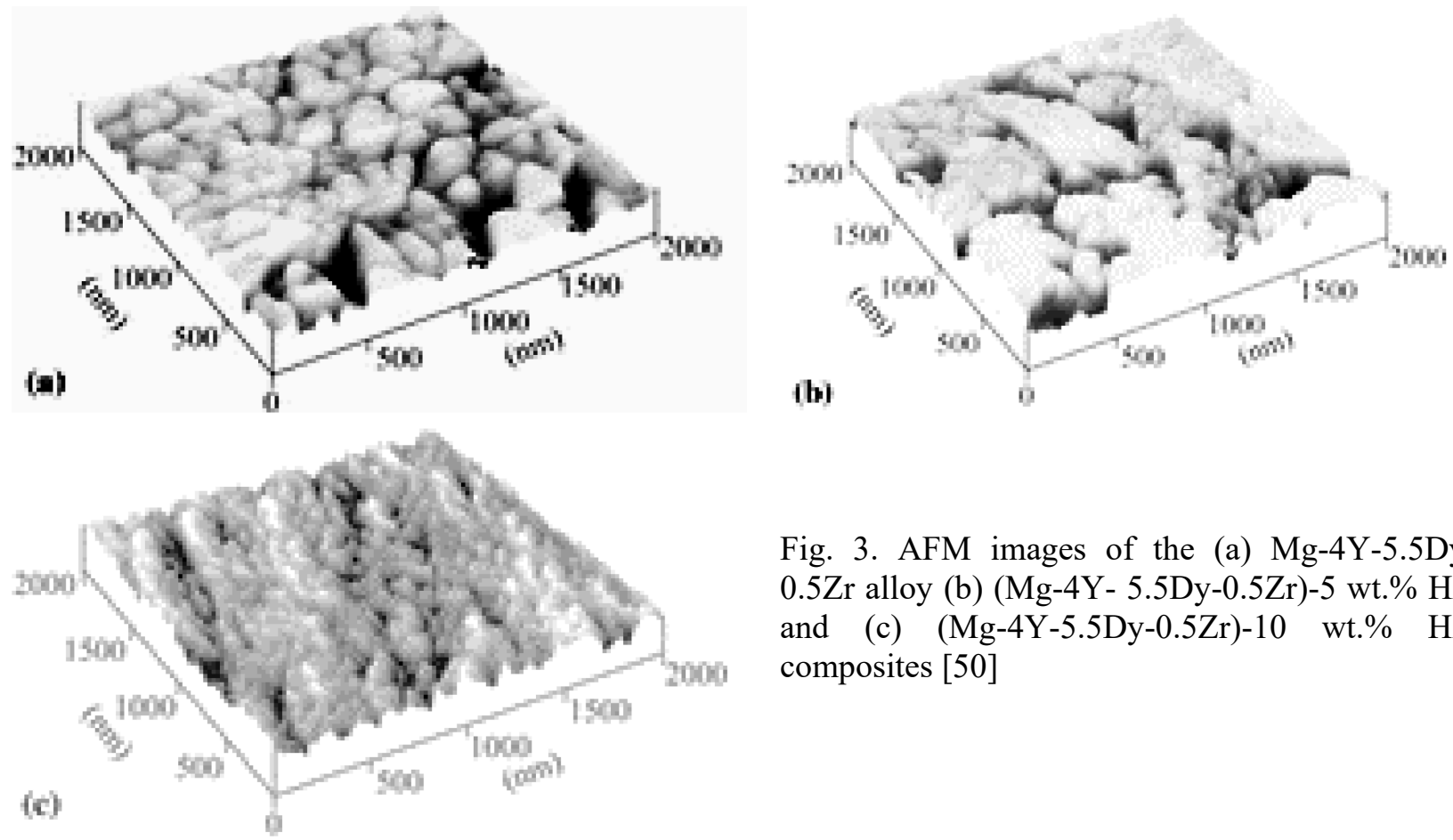

Fig. 3. AFM images of the (a) Mg-4Y-5.5Dy$0.5 \mathrm{Zr}$ alloy (b) (Mg-4Y- 5.5Dy-0.5Zr)-5 wt.\% HA and (c) (Mg-4Y-5.5Dy-0.5Zr)-10 wt. $\%$ HA composites [50]

Kowalski et al. [50] studied the influence of the chemical composition on the microstructure, mechanical and corrosion properties of mechanically alloyed and sintered (Mg-4Y-5.5Dy- $0.5 \mathrm{Zr})-\mathrm{x}$ wt.\% HA composites. Fig. 3 shows the AFM images of (a) Mg-4Y-5.5Dy-0.5Zr alloy (b) (Mg-4Y5.5Dy-0.5Zr)-5 wt.\%HA and (c) (Mg-4Y-5.5Dy-0.5Zr)-10wt.\%HA composites. The size distribution of particles was 35 to $245 \mathrm{~nm}$ for Mg-4Y-5.5Dy-0.5Zr alloy. The average size of the (Mg-4Y-5.5Dy- 0.5Zr)-5 wt. \% HA composite particles is $95 \mathrm{~nm}$. This value is bigger than the average size of the (Mg-4Y-5.5Dy- $0.5 \mathrm{Zr})-10 \mathrm{wt} . \% \mathrm{HA}$ composite particles i.e. $55 \mathrm{~nm}$. Chemical modification of the $\mathrm{Mg}-4 \mathrm{Y}-5.5 \mathrm{Dy}-0.5 \mathrm{Zr}$ alloy by $\mathrm{HA}$ resulted in fine size particles.

There are few more reports related to Mg-alloy composite systems developed from different alloy composition as well as reinforcement materials. Table 6 summarizes the mechanical and corrosion properties of various types of Mg-MMCs in different conditions.

Table 6. Mechanical and corrosion properties of Mg-based MMCs

\begin{tabular}{|c|c|c|c|c|c|}
\hline Material & Condition & $\begin{array}{l}\text { UCS } \\
{[\mathrm{MPa}]}\end{array}$ & $\begin{array}{l}\text { UTS } \\
\text { [MPa] }\end{array}$ & $\mathbf{I}_{\mathrm{corr}}\left[\mathbf{A} / \mathrm{cm}^{2}\right]$ & Ref. \\
\hline $\mathrm{Mg}-2 \mathrm{Zn}-0.5 \mathrm{Ca} / 1 \beta-\mathrm{TCP}$ & $\begin{array}{l}\text { Normal Casting of } \\
\mathrm{Mg}-2 \mathrm{Zn}-0.5 \mathrm{Ca} \text { then } \\
\text { remelting to add TCP }\end{array}$ & - & - & $\begin{array}{c}789.9 \pm 8.8 \\
\mathrm{CR}^{*}(0-36 \mathrm{~h}) \\
{\left[\mathrm{mgcm}^{-2} \mathrm{~h}^{-1}\right]}\end{array}$ & [51] \\
\hline$\beta-\mathrm{Ca}_{3}\left(\mathrm{PO}_{4}\right)_{2} / \mathrm{Mg}-\mathrm{Zn}$ & $\mathrm{PM}+$ extrusion & - & - & $7\left[\mu \mathrm{A} \cdot \mathrm{cm}^{-2}\right]$ & {$[52]$} \\
\hline Mg-Bredigite 40 vol\% & $\mathrm{PM}+$ extrusion & - & 190 & - & {$[53]$} \\
\hline $\operatorname{Mg} 60$ & As-cast & 580 & - & - & {$[54]$} \\
\hline $\operatorname{Mg} 67$ & - & 440 & - & - & {$[54]$} \\
\hline Mg60T40 & - & 800 & - & - & {$[54]$} \\
\hline Mg67T40 & - & 700 & - & - & {$[54]$} \\
\hline BG-5/Mg & PM & - & - & - & {$[55]$} \\
\hline BG-10/Mg & - & - & - & - & {$[55]$} \\
\hline BG-15/Mg & - & - & - & - & {$[55]$} \\
\hline $\mathrm{Mg}-\mathrm{Mn}-\mathrm{Zn}-\mathrm{Zr}$ & PM & - & - & $1.62 \times 10^{-4}$ & [56-57] \\
\hline Mg-Mn-Zn-Zr-5HA & - & - & - & $3.39 \times 10^{-4}$ & [56-57] \\
\hline Mg-Mn-Zn-Zr-5BG & - & - & - & $1.49 \times 10^{-4}$ & {$[56-57]$} \\
\hline
\end{tabular}




\begin{tabular}{|c|c|c|c|c|c|}
\hline Mg-Mn-Zn-Zr-5HA & - & - & - & $2.43 \times 10^{-4}$ & [56-57] \\
\hline Microcrystalline Mg: & - & - & \multirow{6}{*}{ - } & \multirow{6}{*}{$3.34 \times 10^{-4}$} & \multirow{6}{*}[58]{} \\
\hline Mg-CS 10 wt \% & - & 178 & & & \\
\hline Mg-CS $20 \mathrm{wt} \%$ & - & 235 & & & \\
\hline $\mathrm{Mg}-\mathrm{CS} 30 \mathrm{wt} \%$ & - & 232 & & & \\
\hline $\mathrm{Mg}-\mathrm{CS} 40 \mathrm{wt} \%$ & - & 212 & & & \\
\hline $\mathrm{Mg}-\mathrm{CS} 50 \mathrm{wt} \%$ & - & 170 & & & \\
\hline Mg-5HAp & $\mathrm{PM}+$ extrusion & 222 & - & - & {$[59]$} \\
\hline Mg-10HAp & $\mathrm{PM}+$ extrusion & 219 & - & - & [59] \\
\hline Mg-15HAp & $\mathrm{PM}+$ extrusion & 216 & - & - & {$[59]$} \\
\hline $\mathrm{Mg}-0.58\left(\mathrm{vol}_{0} /\right)_{\mathrm{TiO}}$ & - & 285 & 128 & - & {$[60]$} \\
\hline $\mathrm{Mg}-0.97\left(\mathrm{vol}_{0} \%\right) \mathrm{TiO}_{2}$ & - & 278.4 & 154 & - & {$[60]$} \\
\hline Mg-1.98(vol\%) $\mathrm{TiO}_{2}$ & - & 297 & 165 & - & {$[60]$} \\
\hline $\mathrm{Mg}-2.5\left(\mathrm{vol}^{2} \%\right) \mathrm{TiO}_{2}$ & - & 305.5 & 170 & - & {$[60]$} \\
\hline $\mathrm{Mg}-\mathrm{HA}-\mathrm{TiO}_{2}-\mathrm{Mgo}$ & - & 253 & - & 255 & {$[60]$} \\
\hline AZ91-10FA & PM & - & - & $7.4 \times 10^{-5}$ & {$[61]$} \\
\hline AZ91-20FA & PM & - & - & $2.3 \times 10^{-6}$ & {$[61]$} \\
\hline AZ91-30FA & PM & - & - & $3.5 \times 10^{-7}$ & [61] \\
\hline
\end{tabular}

\section{Conclusions}

In recent years, biomaterials for orthopedic applications have evolved from an inert state to a moderate corrosion resistance as well as biodegradability. The possibility to control surface as well as corrosion properties at the micro/nano level constitutes one of the major breakthroughs in $\mathrm{Mg}$ composites, because it opens a whole new range of strategies seeking the desired interaction with the biological environment. With advancements in new alloy designs and nanomaterials, it will be possible soon to realize Mg-alloys and composites as the emerging next-generation biomaterials for multifunctional bone implants with highly bioactive surface and antibacterial characteristics. Metals will keep moving on their journey to become more human friendly for a long lasting relationship with the natural bone and tissue regeneration. Mg-based composites will evolve more strongly with the advancements in manufacturing and nanotechnology enabling its clinical applications more successful.

\section{References}

[1] B.L. Riggs, L.J. Melton III, The worldwide problem of osteoporosis: Insights afforded by epidemiology, Bone, 17 (1995) S505-S511.

[2] E.A. Chrischilles, C.D. Butler, C.S. Davis, R.B. Wallace, A model of lifetime osteoporosis impact, Arch. Intern. Med., 151 (1991) 2026-2032.

[3] B.D. Ratner, A.S. Hoffman, F.J. Schoen, J.E. Lemons, Biomaterials Science: An Introduction to Materials in Medicine, second ed., Academic Press, 2004.

[4] L.L. Hench and I. Thompson, Twenty-first century challenges for biomaterials, J. Royal Soc. Interf., 7 (2010) S379-S391.

[5] M.B. Kannan and R.K.S. Raman, In vitro degradation and mechanical integrity of calciumcontaining magnesium alloys in modified-simulated body fluid, Biomater., 29 (2008) 2306-2314.

[6] M. Niinomi, Recent metallic materials for biomedical applications, Metall. Mater. Trans. A, 33A (2002) 477-486. 
[7] P.S. Walker and B.L. Gold, The tribology (friction, lubrication and wear) of all-metal artificial hip joints, Wear, 17 (1971) 285-299.

[8] J. Brettle, A survey of the literature on metallic surgical implants, Injury, $2 / 1$ (1970) 26-39.

[9] I. Gotman, Characteristics of metals used in implants, J. Endourol., 11 (2009) 383-389.

[10] L.A. Pruitt and A.M. Chakravartula, Mechanics of Biomaterials: Fundamental principles for implant design, MRS Bull., 37 (2012) 698-698.

[11] C. Oldani and A. Dominguez, Titanium as a biomaterial for Implants, in: S.K. Fokter (Eds.), Recent Advances in Arthroplasty, InTech Open, 2012.

[12] P.Siegkas, V.Tagarielli and N.Petrinic, Modelling stochastic foam geometries for FE simulations using 3D Voronoi cells, Procedia Mater. Sci., 4 (2014) 221-226.

[13] L.A. Pruitt and A.M. Chakravartula, Mechanics of Biomaterials: Fundamental principles for implant design, first ed., Cambridge University Press, 2011.

[14] J. Nagels, M. Stokdijk and P.M. Rozing, Stress shielding and bone resorption in shoulder arthroplasty, J. Shoulder Elbow Surg., 12 (2003) 35-39.

[15] J.J. Jacobs, N.J. Hallab, A.K. Skipor and R.M. Urban, Metal degradation products: a cause for concern in metal-metal bearings, Clin. Orthop. Relat. Res., 417 (2003) 139-147.

[16] D.A. Puleo and W.W. Huh, Acute toxicity of metal ions in cultures of osteogenic cells derived from bone marrow stromal cells, J. Appl. Biomater., 6 (1995) 109-116.

[17] M.P. Staiger, A.M. Pietak, J. Huadmai and G. Dias, Magnesium and its alloys as orthopedic biomaterials: A review, Biomater., 27 (2006) 1728-1734.

[18] F.Witte, N. Hort, C. Vogt, S. Cohen, K.U. Kainer, R. Willumeit and F. Feyerabend, Degradable biomaterials based on magnesium corrosion, Curr. Opin. Solid State Mater. Sci., 12 (2008) 63-72.

[19] B.D. Ulery, L.S. Nair and C.T. Laurencin, Biomedical applications of biodegradable polymers, J. Polym. Sci., Part B: Polym. Phys., 49 (2011) 832-864.

[20] F. Witte, V. Kaese, H. Haferkamp, E. Switzer, A. Meyer-Lindenberg, C.J. Wirth and H. Windhagen, In vivo corrosion of four magnesium alloys and the associated bone response, Biomater., 26 (2005) 3557-3563.

[21] M. Purusothaman and M. Sasikumar, Processing/properties and applications of Magnesium based metal matrix composites: A review, Internatio. J. Intellect. Advanc. Resear.Engineer. Computat., 5 (2017) 1995-2007.

[22] Y.K. Pan, C.Z. Chen, D.G. Wang and X. Yu, Microstructure and biological properties of micro-arc oxidation coatings on ZK60 magnesium alloy, J. Biomed. Mater. Res. Part B Appl. Biomater., 10B (2012) 1574-1586.

[23] J.W. Choi, Y.M. Kong, H.E. Kim and I.S. Lee, Reinforcement of hydroxyapatite bioceramic by addition of Ni3Al and Al2O3, J. Am. Ceram. Soc., 81 (1998) 1743-1748.

[24] T.V. Thamaraiselvi and S. Rajeswari, Biological evaluation of bioceramic materials-A review, Trends Biomater. Artif. Organs., 18 (2004) 9-17.

[25] J.E. Sun, M. Chen, G. Cao, Y. Bi, D. Liu and J. Wei, The effect of nano-hydroxyapatite on the microstructure and properties of Mg-3Zn-0.5 Zr alloy, J. Compos Mater., 48 (2014) 825-834.

[26] Y. Chen, Z. Xu, C. Smith and J. Sankar, Recent advances on the development of magnesium alloys for biodegradable implants, Acta Biomater., 10 (2014) 4561-4573.

[27] K.Y. Renkema, R.T. Alexander, R.J. Bindels and J. G. Hoenderop. Calcium and phosphate homeostasis: concerted interplay of new regulators, Ann. Med., 40 (2008) 82-91. 
[28] H.Z. Ye and X.Y. Liu, Review of recent studies in magnesium matrix composites, J. Mater. Sci., 39 (2004) 6153-6171.

[29] R.B. Bell and C.S. Kindsfater, The use of biodegradable plates and screws to stabilize facial fractures, J. Oral Maxillofac. Surg., 64 (2006) 31-39.

[30] P.D. Saltman and L.G. Strause, The role of trace minerals in osteoporosis, The J. Am. Coll. Nutr., 12 (1993) 384-389.

[31] A. Martin and J. Llorca, Mechanical behaviour and failure mechanisms of a binary Mg- 6\% Zn alloy reinforced with SiC particulates, J. Mater. Sci. Engin. A, 201 (1995) 77-87.

[32] D. Tie, F. Feyerabend, W.D. Mueller, R. Schade, K. Liefeith, K.U. Kainer and R. Willumeit, Antibacterial biodegradable Mg-Ag alloys, J. Eur. Cell. Mater., 16 (2013) 284-298.

[33] G.E.J. Poinern, S. Brundavanam and D. Fawcett. Biomedical magnesium alloys: a review of material properties, surface modifications and potential as a biodegradable orthopaedic implant, Amer. J. Biomed. Engin., 2 (2012) 218-240.

[34] L. Liu, F. Yuan, M. Zhao, C. Gao, P. Feng, Y. Yang, S. Yang and C. Shuai, Rare earth element yttrium modified Mg-Al-Zn alloy: Microstructure, degradation properties and hardness, Mater., 10 (2017) 477.

[35] R.Z. Wu, Z.K. Qu and M.L. Zhang, Reviews on the influences of alloying elements on the microstructure and mechanical properties of Mg-Li base alloys, Rev. Adv. Mater. Sci., 24 (2010).35-43.

[36] Z. Li,, X. Gu, S. Lou and Y. Zheng, The development of binary $\mathrm{Mg}-\mathrm{Ca}$ alloys for use as biodegradable materials within bone, Biomater., 29 (2008) 1329-1344.

[37] X. Gu, Y. Zheng, Y. Cheng, S. Zhong and T. Xi, In vitro corrosion and biocompatibility of binary magnesium alloys, Biomater., 30 (2009) 484-498.

[38] X.N. Gu, X.H. Xie, N. Li, Y.F. Zheng, L. Qin, In vitro and in vivo studies on a Mg-Sr binary alloy system developed as a new kind of biodegradable metal, Act. Biomater., 8 (2012) 23602374.

[39] R. Xin, M. Wang, J. Gao, P. Liu and Q. Liu, Effect of microstructure and texture on corrosion resistance of magnesium alloy, Mater. Sci. Foru., 610-613 (2009) 1160-1163.

[40] V. Kaesel, P.-T. Tai, Fr. Bach, H. Haferkamp, F. Witte and H. Windhagen, Approach to control the corrosion of magnesium by alloying. In Magnesium: Proceedings of the 6th International Conference Magnesium Alloys and Their Applications (2005) 534-539.

[41] N. Hort, Y. Huang, D. Fechner, M. Störmer, C. Blawert, F. Witte, C. Vogt, H. Drücker, R.Willumeit, and K. Kainer, Magnesium alloys as implant materials-principles of property design for Mg-RE alloys, Act., Biomater., 6 (2010) 1714-1725.

[42] J. Gray and B. Luan, Protective coatings on magnesium and its alloys - a critical review, J. Alloys Compd., 336 (2002) 88-113.

[43] G. Song, A. Atrens, X. Wu, and B. Zhang, Corrosion behaviour of AZ21, AZ501 and AZ91 in sodium chloride, J. Corro. Sci., 40 (1998)1769-1791.

[44] V. Mouriño and A. R. Boccaccini, Bone tissue engineering therapeutics: controlled drug delivery in three-dimensional scaffolds, J. R. Soc. Interf., 7 (210) 209-227.

[45] H. Wang, Y. Estrin, and Z. Zúberová, Bio-corrosion of a magnesium alloy with different processing histories, Mater. Lett., 62 (2008) 2476-2479.

[46] S.V. Dorozhkin, Calcium orthophosphate coatings on magnesium and its biodegradable alloys, Acta Biomater., 10 (2014) 2919-2934. 
[47] B. Wang, P. Huang, C. Ou, K. Li, B. Yan, and W. Lu, In vitro corrosion and cytocompatibility of ZK60 magnesium alloy coated with hydroxyapatite by a simple chemical conversion process for orthopedic applications, Int. J. Mol. Sci., 14 (2013) 23614-23628.

[48] S. Singh and N. Chauhan, A Evaluation of Pure Mg and Mg-Zn ALLOYS as a Biomaterial in Bone Remodelling-A Review, J. Mater. Sci. Mechan. Engin., 3 (2016) 149-151.

[49] B.R. Sunil, C. Ganapathy, T.S. Kumar and U. Chakkingal, Processing and mechanical behavior of lamellar structured degradable magnesium-hydroxyapatite implants, J. Mech. Behav. Biomed. Mater., 40 (2014) 178-189.

[50] K. Kowalski, M. Nowak, J. Jakubowicz, and M. Jurczyk, The effects of hydroxyapatite addition on the properties of the mechanically alloyed and sintered Mg-RE-Zr alloy, J. Mater. Eng. Perform., 25 (2016) 4469-4477.

[51] Y. Huang, D. Liu, L. Anguilano, C. You, and M. Chen, Fabrication and characterization of a biodegradable Mg-2Zn-0.5Ca/1 $\beta$-TCP composite, Mater. Sci. Eng. C., 54 (2015) 120-132.

[52] Y. Yan, Y. Kang, D. Li, K. Yu, T. Xiao, Y. Deng, H. Dai, Y. Dai, H. Xiong, and H. Fang, Improvement of the mechanical properties and corrosion resistance of biodegradable $\beta-\mathrm{Ca} 3$ (PO4) $2 / \mathrm{Mg}-\mathrm{Zn}$ composites prepared by powder metallurgy: the adding $\beta-\mathrm{Ca}_{3}\left(\mathrm{PO}_{4}\right)_{2}$, hot extrusion and aging treatment, Mater. Sci. Eng. C, 74 (2017) 582-596.

[53] S. N. Dezfuli, Z. Huan, A. Mol, S. Leeflang, J. Chang, and J. Zhou, Advanced bredigitecontaining magnesium-matrix composites for biodegradable bone implant applications, Mater. Sci. Eng. C, 79 (2017) 647-660.

[54] P.-C. Wong, P.-H. Tsai, T.-H. Li, C.-K. Cheng, J. Jang and J. Huang, Degradation behavior and mechanical strength of $\mathrm{Mg}-\mathrm{Zn}-\mathrm{Ca}$ bulk metallic glass composites with $\mathrm{Ti}$ particles as biodegradable materials, J. Alloys Compd., 699 (2017) 914-920.

[55] Y. Wan, T. Cui, W. Li, C. Li, J. Xiao, Y. Zhu, D. Ji, G. Xiong, and H. Luo, Mechanical and biological properties of bioglass/magnesium composites prepared via microwave sintering route, Mater. Des., 99 (2016) 521-527.

[56] K. Kowalski, M. Nowak and M. Jurczyk, Mechanical and Corrosion Properties of Magnesium-Bioceramic Nanocomposites, Arch. Metall. Mater., 61 (2016) 1437-1440.

[57] D. Liu, Y. Liu, Y. Zhao, Y. Huang, and M. Chen, The hot deformation behavior and microstructure evolution of $\mathrm{HA} / \mathrm{Mg}-3 \mathrm{Zn}-0.8 \mathrm{Zr}$ composites for biomedical application, Mater. Sci. Eng. C, 77 (2017) 690-697.

[58] Z. Huan, C. Xu, B. Ma, J. Zhou, and J. Chang, Substantial enhancement of corrosion resistance and bioactivity of magnesium by incorporating calcium silicate particles, RSC Advan., 6 (2016) 47897-47906.

[59] R. del Campo, B. Savoini, A. Munoz, M. Monge, and G. Garcés, Mechanical properties and corrosion behavior of Mg-HAP composites, J. Mech. Behav. Biomed. Mater., 39 (2014) 238246.

[60] S.Z. Khalajabadi, M.R.A. Kadir, S. Izman and M. Kasiri-Asgarani, Microstructural characterization, biocorrosion evaluation and mechanical properties of nanostructured $\mathrm{ZnO}$ and $\mathrm{Si} / \mathrm{ZnO}$ coated $\mathrm{Mg} / \mathrm{HA} / \mathrm{TiO}_{2} / \mathrm{MgO}$ nanocomposites, Surf. Coat. Technol., 277 (2015) 30-43.

[61] M. Razavi, M. Fathi and M. Meratian, Microstructure, mechanical properties and biocorrosion evaluation of biodegradable AZ91-FA nanocomposites for biomedical applications, Mater. Sci. Eng., A 527 (2010) 6938-6944. 